\title{
Analisis Kebijakan Outsourcing Penyelenggaraan Makan Pasien di Rumah Sakit Umum Daerah Sumedang
}

\author{
Dewi Marhaeni Diah Herawati, ${ }^{1}$ Ida Siti Nurparida, ${ }^{2}$ Nita Arisanti ${ }^{3}$ \\ ${ }^{1}$ Departemen Ilmu Gizi Medik Fakultas Kedokteran Universitas Padjadjaran, ${ }^{2}$ Rumah Sakit Umum \\ Daerah Sumedang, ${ }^{3}$ Departemen Ilmu Kesehatan Masyarakat Fakultas Kedokteran Universitas \\ Padjadjaran
}

\begin{abstract}
Abstrak
Prevalensi malnutrisi pasien rawat inap di rumah sakit cukup tinggi. Pelayanan gizi diharapkan dapat mengatasi terjadinya malnutrisi di rumah sakit. Penelitian ini bertujuan untuk melakukan analisis terhadap kebijakan outsourcing penyelenggaraan makan pasien di Rumah Sakit Umum Sumedang. Desain penelitian adalah mixed method dengan strategi concurrent embedded. Pengambilan sampel kualitatif dilakukan secara purposive sampling. Subjek penelitian adalah tim pelayanan gizi rumah sakit. Sampel kuantitatif menggunakan stratified simple random sampling, diperoleh jumlah sampel 154 pasien. Pengukuran status gizi pasien menggunakan subjective global assessment. Penelitian dilakukan pada bulan November sampai Desember 2012. Mekanisme penyediaan makan cukup terstruktur dan jelas, meskipun masih ada Standar Operasional Prosedur (SOP) yang belum dimiliki katering seperti SOP untuk menu pasien anak-anak, penyiapan logistik dan membersihkan peralatan makan pasien. Beban kerja karyawan katering sangat tinggi dan rangkap tugas. Tim Panitia Asuhan Gizi (PAG) khususnya perawat dan petugas gizi dapat bekerja lebih baik, namun belum memiliki perencanaan stratejik untuk pelayanan gizi. Kapasitas tim PAG dalam pelayanan gizi belum optimal. Terdapat peningkatan gizi buruk dari 1,9\% sebelum perawatan menjadi 13\% setelah perawatan. Simpulan, penyelenggaraan makan dengan sistem outsourcing belum berdampak pada peningkatan status gizi pasien, namun mekanisme layanan asuhan gizi dan penyediaan makan menjadi lebih jelas dan lebih baik. [MKB. 2014;46(4):234-40]
\end{abstract}

Kata kunci: Analisis kebijakan, outsourcing, penyelenggaraan makan

\section{Policy Analysis of Food Services Outsourcing in Sumedang District Hospital}

\begin{abstract}
The prevalence of malnutrition remains high in hospital inpatients. Nutritional services can overcome such problem. This study aimed to perform a policy analysis of food service outsourcing in Sumedang District Hospital. The design of this study was a mixed method using a concurrent embedded strategy. The purposive sampling was chosen for the qualitative study in which the hospital nutritionist team members became the subjects. The sampling for the quantitative study was performed using the stratified simple random sampling. About 154 patients were selected as subjects. The subjective global assesment was used as the instrument. The study was conducted from November to December 2012. The food service mechanism was well structured and clear even though there were missing Standard Operating Procedures (SOPs) such as SOPs for pediatric patient menus, logistic preparation, and patient meal equipment cleaning. Catering employees had a very high workload and were multitasking. The Nutrition Care Committee Team may work better. There was no strategic plan for nutrition services. The capacity of the team was not optimum in terms of nutritional care. The proportion of malnutrition increased from $1.9 \%$ to $13 \%$ after hospitalization when compared to the pre-hospitalization condition. In conclusion, the outsourcing system for food services has no impact on patients' nutrition status; however, it is apparent that a clear and better mechanism of nutrition care and food provision is needed. [MKB. 2014;46(4):234-40]
\end{abstract}

Key words: Food services, outsourcing, policy analysis

Korespondensi: Dr. Dewi Marhaeni Diah Herawati, drg., M.Si, Departemen Ilmu Gizi Medik Fakultas Kedokteran Universitas Padjadjaran, Jalan Prof. Eijkman No. 38 Bandung 40161, mobile 082126033975, e-mail dewimdh@yahoo.com 


\section{Pendahuluan}

Permasalahan tingginya malnutrisi pada pasien yang menjalani rawat inap di rumah sakit merupakan suatu fenomena yang banyak terjadi di seluruh rumah sakit di dunia. ${ }^{1-4}$ Penelitian di rumah sakit Indonesia pada beberapa kasus penyakit terlihat bahwa pasien yang mengalami malnutrisi sekitar 40 sampai 70\%. ${ }^{5}$ Penyebab permasalahan tersebut sangat kompleks, selain karena kondisi pasien yang mengalami penyakit kronik, pasien tidak mendapat pelayanan gizi secara adekuat, dan lain-lain. Pelayanan gizi yang tidak adekuat sangat terkait dengan penyelenggaraan makan di rumah sakit. Penyelenggaraan makan di rumah sakit diduga belum banyak yang paham dalam melakukan interpretasi kebutuhan gizi yang diminta oleh dokter. Penyelenggaraan makan juga sangat terbatas kemampuannya dalam membuat variasi menu makan setiap pasien, pengolahan makan yang belum tepat, serta belum melakukan evaluasi yang berkesinambungan.

Kementrian Kesehatan RI telah mengeluarkan kebijakan pedoman pelayanan gizi di rumah sakit. Pelayanan gizi rumah sakit antara lain asuhan gizi, penyelenggaraan makan, penelitian, dan pengembangannya. ${ }^{6}$ Kebijakan Kemenkes tersebut menjadi acuan beberapa rumah sakit dalam melakukan outsourcing penyelenggaraan makan. Penyelenggaraan makan itu merupakan bagian yang tidak terpisahkan dalam pemberian perawatan kepada pasien, oleh karena itu pihak manajemen rumah sakit seharusnya melakukan pemantauan terhadap penyelenggaraan makan di rumah sakit.

Sejak tahun 2003, Rumah Sakit Umum Daerah (RSUD) Sumedang merupakan salah satu rumah sakit yang telah melakukan outsourcing dalam penyelengaraan makan. Keadaan ini dimaksudkan agar para petugas di unit pelayanan gizi dapat memberikan pelayanan asuhan gizi dengan lebih baik, selain itu juga dapat melakukan pengamatan permasalahan malnutrisi di rumah sakit. Penelitian bertujuan untuk melakukan analisis terhadap kebijakan penyelenggaraan makan dengan sistem outsourcing di RSUD Sumedang.

\section{Metode}

Desain penelitian ini menggunakan mixed method dengan strategi concurrent embedded. ${ }^{7}$ Strategi pendekatan kualitatif yang dipergunakan adalah studi kasus, pengumpulan data dilakukan melalui wawancara mendalam. Strategi untuk pendekatan kuantitatif yang dipergunakan adalah deskriptif potong lintang. Subjek penelitian kualitatif adalah tim asuhan gizi ruangan, tim manajemen, serta petugas katering. Pengambilan sampel kualitatif dilakukan dengan cara purposive sampling dan diperoleh sampel jenuh sejumlah 10 informan. Pengambilan sampel kuantitatif dilakukan secara stratified simple random sampling pada pasien yang dirawat di RSUD Kabupaten Sumedang baik di ruang rawat inap kelas VIP, Utama maupun kelas I-III dan diperoleh sampel sejumlah 154 pasien. Adapun gambaran responden seperti pada Tabel 1.

Penelitian dilakukan pada tanggal 1 November sampai dengan 31 Desember 2012. Pengumpulan data kuantitatif dilakukan melalui data primer dan data skunder. Data primer diambil dengan melakukan penilaian status gizi pasien melalui metode subjective global assesment (SGA). Data skunder diambil dari dokumen pendukung. Analisis data kualitatif yaitu meliputi tahapan transkripsi, reduksi, coding dan kategorisasi, serta penetapan tema. ${ }^{7,8}$ Analisis data kuantitatif dilakukan secara deskriptif.

\section{Hasil}

Rumah Sakit Umum Daerah Sumedang sejak tahun 2003 telah melakukan perubahan dalam sistem penyelenggaraan makanan, yaitu dari sistem swakelola menjadi sistem outsourcing. Pada tahun 2009 Pemerintah telah menetapkan

Tabel 1 Persentase Responden berdasarkan Kelas Perawatan, Lama Dirawat, dan Kasus Penyakit

\begin{tabular}{lcc}
\hline & $\mathbf{n = 1 5 4}$ & $\mathbf{\%}$ \\
\hline Kelas perawatan & & \\
VIP & 12 & 7,9 \\
Utama & 13 & 8,4 \\
Kelas I & 16 & 10,4 \\
Kelas II & 23 & 14,9 \\
Kelas III & 90 & 58,4 \\
Lama dirawat (hari) & & \\
1-6 & 126 & 81,9 \\
$7-12$ & 26 & 16,9 \\
13-18 & 0 & 0 \\
19-24 & 1 & 0,6 \\
25-30 & 1 & 0,6 \\
Kasus penyakit & & \\
Anak & 22 & 14,3 \\
Bedah & 40 & 26,0 \\
Kandungan & 24 & 15,6 \\
Dalam & 68 & 44,1 \\
Total & 154 & 100 \\
\hline
\end{tabular}


pengelolaan RSUD menjadi BLUD, keadaan ini berdampak penyelenggaraan makan dengan sistem outsourcing dibuat dalam bentuk Kerja Sama Operasi (KSO). Kebijakan tersebut sejalan dengan peningkatan RSUD Sumedang menjadi tipe B nonpendidikan. Bentuk KSO yang dipakai oleh RSUD Sumedang adalah Build Operate and Transfer (BOT). Katering memiliki kewenangan dalam pengendalian pengelolaan aset pada akhir masa perjanjian maka aset katering diserahkan kepada RSUD Sumedang.

Penyelenggaraan makan dimulai permintaan menu makan dari instalasi gizi kepada pihak katering. Katering telah mempunyai daftar menu makan dan standar jumlah makanan yang akan diberikan kepada pasien. Saat ini, standar jumlah makanan dan menu makan pasien lebih banyak ditetapkan oleh pihak katering. Petugas katering menginginkan pembuatan standar jumlah makan dan juga menu makan pasien menjadi tanggung jawab bersama instalasi gizi rumah sakit dengan katering. Keinginan tersebut terungkap dari hasil wawancara di bawah ini:

“..........selama ini yang saya rasakan kok yang berperan ini hanya dari katering, dari pihak rumah sakit tidak ada....Tapi alangkah baiknya dari rumah sakit pun ada ketentuan nih harus begini, kalau sayur tuh harus begini... namanya juga dagang ya, kalau kami licik gitu ya bisa saja dikurangi ........misalnya kalau sayur bisa saja dikurangi standarnya.... daging harusnya 40 gram bisa saja dikurangi jadi tidak kelihatan kan.....(Responden 1).

Petugas masak menerjemahkan permintaan menu dari instalasi gizi dan kemudian meminta order bahan makanan kepada petugas gudang atau logistik dengan mengacu tabulasi yang sudah dimiliki pihak katering. Bahan makanan diolah menjadi makanan siap saji, kemudian dilakukan pemorsian oleh petugas masak. Setelah dilakukan pemorsian maka petugas pramusaji mengantar atau mendistribusikan ke seluruh ruang rawat inap. Petugas pramusaji juga bertugas membantu pemorsian serta memotong buah, menyiapkan tisu dan alat makan, setelah itu dilakukan clearup oleh petugas pramusaji. Semua alat makan dibawa ke dapur untuk dapat dilakukan pencucian piring.

Instalasi gizi rumah sakit dan katering telah membuat beberapa SOP (Standard Operating Procedur). Adapun SOP yang telah dibuat oleh instalasi gizi yaitu meliputi prosedur penyusunan menu, penyusunan pengelolaan produksi dan distribusi, penanganan makanan dan alat makan untuk pasien dengan penyakit menular, serta penyimpanan dan penanganan bahan makanan. Pembuatan SOP tersebut telah melibatkan panitia asuhan gizi (PAG). Adapun tujuannya adalah agar kegiatan pelayanan gizi dapat terintegrasi dengan pelayanan kesehatan lain di rumah sakit. Katering telah mempunyai SOP pengolahan makanan, SOP pembuatan menu pasien dewasa, dan SOP distribusi makanan. Katering belum memiliki SOP untuk pembuatan menu makan pasien anakanak, SOP penyiapan logistik, serta SOP untuk mencuci alat makan pasien. SOP mencuci alat makan ini sangat penting agar tidak menimbulkan kekhawatiran petugas pencuci piring terhadap terjadinya penularan penyakit.

Jumlah pelaksana pelayanan katering yang bertugas di instalasi bagian gizi RSUD Sumedang sampai dengan tahun 2012 terdapat sebanyak 50 orang, jumlah tersebut belum ideal. Kualifikasi pelaksana pelayanan katering tersebut mayoritas mempunyai pendidikan SMA yaitu sebanyak 40 orang, pendidikan sarjana 2 orang, supervisor memiliki pendidikan D-1 Gizi, dan belum ada tenaga yang memiliki kualifikasi pendidikan S-2 Gizi. Kualitas tenaga katering untuk melakukan kegiatan penyelenggaraan makan terlihat masih belum memadai. Petugas masak terdapat 8 orang termasuk petugas yang membantu memasak, belum ada petugas chief cook, sedangkan petugas pastry ada 2 orang. Kebanyakan petugas masak hanya bermodal pengalaman.

Petugaskatering rata-rata mengatakan memiliki tugas berat, mereka bekerja multi tasking, seperti menjadi pramusaji dan peracik makanan pasien. Menurut petugas seharusnya katering memiliki tenaga untuk purchasing, logistik, memasak, meracik, distribusi, administrasi serta supervisi, dan juga manajemen operasional. Beban tugas yang paling berat sangat dirasakan oleh petugas distribusi makanan, beban petugas itu bertambah lebih berat karena mereka juga harus memasak untuk karyawan. Hal tersebut terungkap dari hasil wawancara di bawah ini:

“.....Tapi yang jadi beban sekarang teh yaitu dengan nambahnya makanan untuk pegawai yang sekarang dibebankan ke kita, kalau dulu sih ada pegawai khusus yang masakin untuk makanan pegawai. Jadi dampaknya gitu bu.... masakan juga jadi tidak fokus...." (Responden 3).

Beban yang berat juga dirasakan oleh petugas supervisor, karena manajer operasional jarang sekali datang mengunjungi sehingga supervisor mengerjakan tugas manajer operasional. Katering belum memiliki petugas yang berlatar belakang ahli gizi, oleh karena ahli gizi dapat berperan memantau dan mengontrol kualitas makanan dari bahan sampai menjadi makanan saji. Selama ini yang berkuasa untuk urusan dapur adalah petugas masak, seperti ungkapan responden di bawah ini: “..............Tugasnya ahli gizi katering adalah memantau dan mengontrol kualitas makanan dari bahan sampai jadi.... Kemudian yang paling 
penting lagi untuk masukan aja kalau di dapur ini bukan cook yang berkuasa tapi harusnya ahli gizi gitu....." (Responden1).

Pada tahun 2007, RSUD Sumedang telah membentuk Panitia Asuhan Gizi (PAG), dengan SK Direktur No. 445/326/RSU/ 2007 tentang "Pembentukan Tim Asuhan Gizi di Lingkungan RSUD Sumedang. Kedudukan Tim PAG berada di bawah Komite Medik RS. Ketua Tim PAG adalah dokter internis, sedangkan sekretarisnya adalah ahli gizi. Adapun anggotanya meliputi dokter spesialis anak, bedah dan kebidanan, serta perawat dan farmasi. Tujuan dibentuknya Tim PAG adalah untuk memberikan masukan kepada Direktur RS tentang manajemen penyelenggaraan makanan dan juga pelaksanaan asuhan gizi di setiap ruangan, sehingga status gizi pasien dapat meningkat. Layanan asuhan gizi merupakan tanggung jawab instalasi gizi, namun mereka harus melakukan koordinasi dengan tim PAG. Pelaksanaan layanan asuhan gizi harus dilakukan oleh tim, bukan bekerja sendiri.

Mekanisme layanan gizi tersebut dimulai dari dokter spesialis yang menulis kebutuhan nutrisi didasarkan diagnosis masalah gizi pasien untuk diberikan kepada instalasi gizi. Instalasi gizi akan menerjemahkan kebutuhan gizi dalam bentuk menu makanan, kemudian diteruskan kepada pihak katering. Problem yang ada, tidak seluruh dokter spesialis memahami pembuatan resep zat gizi yang dibutuhkan pasien. Hal ini mengakibatkan pihak instalasi gizi mengalami kesulitan dalam membuat kebutuhan zat gizi pada pasien rawat inap. Akibatnya pihak instalasi gizi sering mencoba melakukan analisis sendiri dalam membuat kebutuhan gizi bagi pasien. Resep diet yang tepat dan jelas, akan memudahkan petugas instalasi gizi untuk menerjemahkannya menjadi menu makan pasien.

Kebijakan outsourcing membuat tenaga gizi dapat bekerja lebih baik dan mereka dapat lebih berperan dalam memberikan layanan asuhan gizi di ruang rawat inap. Sewaktu masih swakelola, petugas gizi mempunyai kesibukan yang lebih banyak di dapur untuk melakukan pengolahan dan distribusi makanan. Tenaga perawat dapat melakukan layanan asuhan keperawatan, tidak lagi mengurus bagaimana distribusi makanan pasien ke ruangan. Petugas gizi selalu melakukan koordinasi dengan perawat dalam melaksanakan layanan asuhan gizi, terutama ketika perawat membutuhkan menu diet yang baik untuk pasien.

Pelaksanaan layanan asuhan gizi dilakukan di setiap ruangan dengan kondisi yang berbeda. Ruang pelayanan anak belum memiliki standar yang baku dalam layanan asuhan gizi. Keadaan tersebut disebabkan oleh karena belum ada menu khusus untuk pasien anak. Protap layanan asuhan gizi pasien dewasa memakai skrining, belum dilakukan asesmen, diagnosis, intervensi serta monitoring dan evaluasi gizi (ADIME). Kepala Instalasi Gizi telah membuat SOP layanan asuhan gizi, namun masih bersifat umum dan belum memenuhi kebutuhan setiap ruang perawatan. Petugas gizi menginginkan tetap ada protap untuk layanan asuhan gizi di tiap-tiap ruang perawatan. Protap yang jelas akan sangat membantu mereka dalam menjalankan tugasnya, dengan demikian mereka tidak melakukan kegiatan yang bersifat "mencoba-coba".

Kegiatan monitoring pada evaluasi (monev) layanan asuhan gizi belum berjalan dengan baik serta belum terprogam dan terjadwal. Petugas menginginkan kegiatan monev dapat dilakukan secara rutin dalam tempo 3 atau 6 bulan, agar mendapat masukan sehingga dapat dipergunakan dalam perbaikan layanan.

Jumlah pelaksana yang ada di instalasi gizi ada 15 orang dengan rincian S-2 Ilmu Kesehatan Masyarakat ada 1 orang (asal S-1 Gizi), Sarjana Kesehatan Masyarakat ada 1 orang, D-4 gizi ada 2 orang, D-3 gizi ada 7 orang dan SMA ada 4 orang. Kepala instalasi gizi memiliki pendidikan D-4 gizi. Petugas yang memiliki pendidikan SMA berfungsi sebagai pegawai administrasi. Petugas dengan dasar pendidikan D-3 pada umumnya kurang percaya diri dalam memberikan layanan asuhan gizi. Petugas merasa keilmuan tentang asuhan gizi masih sangat kurang dibandingkan dengan yang sudah mempunyai pendidikan S-1 dan S-2. Pada umumnya petugas yang masih berpendidikan D-3 menginginkan bekerja dalam tim, agar mereka dapat belajar dari petugas lain yang pendidikannya lebih tinggi. Selain itu,

Tabel 2 Status Gizi Sebelum dan Setelah Mendapatkan Pelayanan Gizi

\begin{tabular}{lcccc}
\hline \multirow{2}{*}{ Status Gizi } & \multicolumn{2}{c}{ Sebelum } & \multicolumn{3}{c}{ Sesudah } \\
\cline { 2 - 5 } & $\mathbf{n}$ & $\mathbf{\%}$ & $\mathbf{n}$ & $\mathbf{\%}$ \\
\hline Baik & 58 & 37,7 & 51 & 33,1 \\
Kurang & 93 & 60,4 & 83 & 53,9 \\
Buruk & 3 & 1,9 & 20 & 13,0 \\
& 154 & 100 & 154 & 100 \\
\hline
\end{tabular}


kekurangan yang mereka miliki dapat diatasi oleh teman yang ada dalam tim. Petugas yang masih berpendidikan D-3 juga menginginkan agar ada pelatihan, seperti ungkapan di bawah ini:

“....Terus mungkin untuk SDM sendiri untuk lebih memaksimalkan perlu pelatihan, sharing dengan yang mempunyai ilmunya sehingga ilmu bisa dikembangkan, kan kita dari D-3 Gizi tahu apa sih kekurangannya sebatas mana? tapi kalau ada sharing, komunikasi, delegasi gitu kan kita akan mempelajari yang kekurangan itu bisa tertutupi. tapi kenyataannya kita belum melaksanakan semuanya....."(Responden 4).

Jumlah petugas gizi yang ada dirasakan masih belum dapat mencukupi kebutuhan, karena belum semua kelas perawatan terdapat petugas gizinya. Hal ini disebabkan karena keterbatasan jumlah petugas gizi.

Penilaian mutu ini didasarkan atas persepsi provider, bukan hasil wawancara dengan pasien. Setelah penyelenggaraan makanan dilaksanakan pihak ketiga, pada umumnya petugas mengatakan bahwa mutu layanan asuhan gizi menjadi lebih baik apabila dibandingkan dengan ketika masih swakelola. Perubahan terjadi dalam penampilan makanan dan juga pemberian layanan kepada pasien. Petugas pada umumnya menginginkan kualitas para tenaga katering ditingkatkan, baik keterampilan atau pengetahuan. Mutu layanan asuhan gizi tidak hanya ditentukan oleh petugas gizi yang memberikan layanan asuhan gizi namun harus ada dukungan dari organisasi rumah sakit maupun pihak katering.

“......Dari sumber daya manusia sendiri mungkin harus yang terampil dan menguasai betul, terus ada dukungan organisasi ya, dukungan dari pihak katering juga....." (Responden 4).

Menurut pendapat perawat, layanan asuhan gizi juga telah mengalami peningkatan terutama dalam penyediaan men. Saat ini petugas gizi telah dapat menyediakan menu diet yang dibutuhkan oleh perawat seperti penyediaan makanan cair dalam bentuk formula. Pada beberapa kasus, tidak seluruh kebutuhan zat gizi dapat dipenuhi oleh pihak katering. Sebagai contoh kasus adalah pasien dewasa yang memerlukan makanan lunak, oleh katering diberikan bubur, namun lauk yang diberikan tetap tidak lunak. Hal ini menyebabkan tidak semua hidangan dapat dimakan oleh pasien sehingga banyak yang terbuang, akibatnya dapat berdampak menurunkan status gizi pasien.

".......jadi makanan tidak sesuai kebutuhan pasien ya, dampaknya banyak makanan tidak dimakan ya ujung-ujungna mah pasien tetep aja status gizina moal bagus...produk makanan harus sesuai kebutuhan terutama pemilihan makanan pasien, pemberian makanan harus tepat terutama dietnya. Kalau melihat seperti ini ternyata sangat kurang ya.." (Responden 6).

Instalasi gizi diharapkan mampu melakukan pengawasan terhadap pihak katering, hal ini penting agar dapat dilakukan quality continous improvement. Salah satu kendala mengapa mutu layanan asuhan gizi belum dapat berjalan dengan baik karena koordinasi antara instalasi gizi dan pihak katering belum berjalan secara rutin. Belum ada interaksi yang baik antara TAG, instalasi gizi, dan pihak katering dalam hal perencanaan, pelaksanaan, monitoring, dan juga evaluasi agar tercapai quality continous improvement.

“........kurang adanya koordinasi antara katering dan instalasi gizi mungkin karena kurangnya pertemuan rutin dan belum terjadwal..... (Responden 7).

Status gizi pasien diukur dengan menggunakan SGA dan dilakukan pada saat masuk ruang rawat inap serta pada saat pasien akan keluar dari rumah sakit.

Hasil pengukuran itu menunjukkan penurunan persentase pasien yang memiliki gizi baik dan peningkatan persentase pasien yang mempunyai gizi buruk.

\section{Pembahasan}

Penyelenggaraan makan di rumah sakit tidak seperti penyelenggaraan makan di hotel atau rumah makan, karena setiap pasien membutuhkan asupan makanan yang sangat berbeda untuk memenuhi kebutuhan gizi. Pasien dengan kondisi gizi kurang membutuhkan asupan makan berbeda dengan pasien yang memiliki kondisi gizi lebih, demikian pula pasien dengan penyakit infeksi kronik membutuhkan diet yang berbeda pula.

Penyelenggaraan makan di rumah sakit agar mampu menjadi pendukung perawatan pasien yang sedang menjalani rawat inap seharusnya dilakukan oleh sebuah perusahaan katering yang profesional dan khusus melayani pasien. Oleh karena itu, katering yang mengelola harus paham betul tentang pemilihan bahan makan, pembuatan menu yang tepat, pengolahan makan, distribusi sampai dengan evaluasi. Penyelenggara makan seharusnya dapat melakukan upaya perbaikan dan edukasi pada pasien agar pelayanan makan di rumah sakit sesuai dengan kebutuhan dan harapan pasien. ${ }^{9}$ Katering untuk rumah sakit tidak mungkin dilakukan oleh katering untuk hotel, rumah makan ataupun katering untuk pesta. Berdasarkan hasil penelitian, banyak negara yang telah melakukan outsourcing penyelenggaraan makan oleh karena diyakini dapat memberikan pelayanan yang tentunya lebih baik. ${ }^{10}$ Kebijakan outsourcing katering dimaksudkan agar terjadi efisiensi dalam pembiayaan dan peningkatan 
kualitas pelayanan. ${ }^{11}$

Outsourcing penyelenggaraan makanan di Rumah Sakit Umum Sumedang dilaksanakan oleh katering yang sebenarnya cukup profesional karena khusus melayani pasien. Mekanisme penyelenggaraan makan yang dilakukan oleh katering sudah hampir sesuai dengan standar yang dibuat Kemenkes, ${ }^{6}$ hanya ada 2 kegiatan yang tampaknya belum dilakukan yaitu pencatatan dan pelaporan serta evaluasi. Berdasarkan standar Kemenkes setelah dilakukan distribusi makanan seharusnya katering melakukan pencatatan dan pelaporan serta melakukan evaluasi terhadap menu makan yang akan disajikan untuk pasien. Faktor penting lainnya yang perlu diperhatikan katering adalah penyajian makanan yang dapat memenuhi kebutuhan energi dan protein pasien. Evaluasi dapat dilakukan dengan melihat sisa makanan yang dihidangkan, jika terdapat banyak sisa makanan kemungkinan besar menu makan tersebut tidak dapat menggugah selera makan pasien. Evaluasi diharapkan dapat melibatkan pasien, sehingga menu makan yang dihidangkan sesuai dengan harapan dan kebutuhan pasien.

Jumlah tenaga katering yang berlatar belakang dietisien yang minimal menyebabkan katering belum mampu memberikan menu makan dan sediaan makan yang tepat dan dibutuhkan oleh pasien. Keadaan ini sesuai dengan penelitian yang dilakukan Diez-Garcia dkk. ${ }^{12}$ yang menyatakan bahwa kapasitas petugas teknis layanan katering sangat berpengaruh dalam pemberian menu diet pada pasien. Hasil penelitian ini sesuai dengan penelitian oleh Diez-Garcia dkk. ${ }^{13}$ yang menyatakan bahwa kapasitas petugas layanan katering dan layanan asuhan gizi memberikan peran yang sangat penting dalam pelayanan gizi di rumah sakit.

Katering sebaiknya memiliki petugas untuk purchasing, logistik, memasak, chief cook, meracik, distribusi, administrasi dan supervisi, serta manajemen operasional. Masing-masing petugas memiliki diskripsi tugas pokok dan fungsi yang jelas. Hal ini dimaksudkan agar beban kerja petugas katering dapat lebih proporsional dan tidak terjadi multi tasking pada petugas. Seluruh mekanisme dalam pengelolaan makan harus dibuat dalam prosedur tetap (protap) atau SOP yang jelas. Katering perlu menambahkan SOP yang belum ada seperti penyiapan menu pasien, menu pasien anak, penyiapan logistik, meracik makanan, mencuci peralatan makan, membuang sampah masakan dan sisa makanan pasien, serta evaluasi menu pasien.

Saat ini di Indonesia belum banyak tersedia katering yang khusus melayani pasien. Sistem outsourcing lebih banyak dikenal di dunia swasta khususnya dalam upaya penyediaan tenaga kerja.
Tujuan dilakukan outsourcing adalah agar terjadi efisiensi dalam biaya produksi, karena terjadi proses pemindahan tanggung jawab dari sebuah perusahaan kepada vendor..$^{14}$

Keberadaan tim PAG di RSUD Sumedang merupakan terobosan yang dibuat oleh pihak manajemen rumah sakit dalam mengatasi pasien yang mengalami malnutrisi. Peran tim PAG dalam layanan asuhan gizi terlihat cukup baik serta dapat memberikan kejelasan dalam mekanisme layanan asuhan gizi. Pada umumnya rumah sakit besar di luar negeri telah memiliki Steering Komite Nutrisi (SKN) dan Tim Dukungan Nutrisi (TDN), di Indonesia TDN dikenal sebagai tim PAG. Keberadaan SKN dan TDN di rumah sakit sangat bermanfaat dalam memantau penanganan malnutrisi pada pasien rawat inap.

Permasalahan di RSUD Sumedang adalah belum memiliki dokter spesialis gizi, sehingga layanan asuhan gizi diampu oleh spesialis lain. Dokter spesialis internis, bedah, dan kandungan memiliki tugas pokok sendiri, yaitu memberikan pelayanan terapi sesuai kompetensi yang mereka miliki. Tugas manajemen rumah sakit untuk dapat menjadi pengampu layanan asuhan gizi membuat beban ganda yang cukup berat bagi para dokter tersebut. Jika rumah sakit belum dapat memiliki dokter spesialis gizi, perlu dilakukan penguatan SDM baik untuk dokter spesialis, dokter umum, maupun staf di instalasi gizi.

Penguatan untuk petugas instalasi gizi dapat berupa peningkatan pendidikan dari D-1 menjadi D-3. Kepala ruang instalasi gizi akan lebih baik lagi jika dijabat oleh petugas yang telah memiliki pendidikan S-2 yang sesuai dengan jabatannya. Staf instalasi gizi yang berpendididkan S-2 perlu ditambah lagi. Pentingnya penguatan seluruh tenaga yang terlibat dalam pelayanan gizi seperti dokter, perawat maupun dietisien, sejalan dengan penelitian yang dilakukan oleh Diez-Garcia dkk. ${ }^{13}$

Peran tim PAG perlu dilakukan revitalisasi agar supaya seluruh proses manajemen mulai dari perencanaan sampai dengan evaluasi dapat dilaksanakan dengan baik dan optimal. Kegiatan koordinasi dan evaluasi sangat penting dibenahi dan juga ditingkatkan kegiatannya, agar dapat diketahui dengan detil apa yang menjadi pokok permasalahannya. Tim PAG perlu melakukan evaluasi terhadap seluruh SOP yang telah ada. Jika SOP tidak dilaksanakan dengan baik oleh petugas, apakah ada sangsinya? Berdasarkan hasil analisis, tim PAG perlu menambahkan SOP untuk pengawasan mutu penyelenggaraan makan. Manajer RSUD Sumedang telah mengaplikasikan ilmu manajemen dengan baik, oleh karena penyelenggaraan makan untuk pasien di rumah sakit telah menjadi isu manajemen. Hal tersebut sesuai dengan penelitian Kondrup. ${ }^{15}$ Menurut 
Lassen dkk. ${ }^{16}$ layanan gizi dapat menurunkan kejadian malnutrisi bila manajemen rumah sakit menjadikan pelayanan gizi sebagai prioritas, pelaksana yang terlibat mempunyai kompetensi dan juga komitmen, katering mampu menyajikan hidangan makanan sesuai kebutuhan pasien serta selalu melakukan evaluasi serta pasien menerima informasi pilihan makanan dan mendapat edukasi tentang makanan.

Kebijakan outsourcing dalam penyelenggaraan makan pasien yang dibuat oleh direktur RSUD Sumedang merupakan kebijakan yang tepat dalam mengatasi permasalahan tingginya malnutrisi di RSUD Sumedang. Saat ini kebijakan tersebut belum dapat berdampak meningkatkan status gizi pasien. Peningkatan status gizi pasien tidak hanya dipengaruhi oleh penyelenggaraan makan karena perkiraan kebutuhan gizi yang akurat merupakan interaksi dokter spesialis dan dietisien, dengan penyelenggara makanan. Kebijakan ini telah berdampak pada peningkatan penyediaan menu makan, penampilan makan dan juga pemberian layanan, selain itu petugas gizi dan perawat dapat menjalankan tugas pokok dan fungsinya sehingga mekanisme layanan asuhan gizi dapat berjalan lebih baik.

Kebijakan outsourcing dapat terus dilanjutkan oleh manajer rumah sakit dengan melakukan beberapa perbaikan baik dari sisi manajer rumah sakit maupun penyelenggara makanan. Manajer rumah sakit diharapkan melakukan pengawasan mutu internal dalam pelayanan gizi, baik yang dilakukan oleh tim layanan asuhan gizi maupun penyelenggara makan pasien serta menyediakan sarana pendukung layanan gizi. Kapasitas SDM dalam pemberian layanan asuhan gizi perlu ditingkatkan. TAPG Rumah Sakit menyediakan protap tentang layanan asuhan gizi di setiap ruangan rawat inap. Pihak penyelenggara makanan dapat menyediakan SDM dengan latar belakang pendidikan gizi sebanyak 20 persen, melengkapi SOP yang belum ada, serta melakukan analisis beban kerja staf.

\section{Daftar Pustaka}

1. Chai J, Chu FCS, Chow TW, Shum NC. Prevalence of malnutrition and its risk factors stroke patients residing in an infirmary. Singapore Med J. 2008;49(4):290-6.

2. Joosten KFM, Hulst JM. Malnutrition in pediatric hospital patient. Nutrition J. 2011;27:133-7.
3. Barker LA, Gout BS, Crowe TC. Hospital malnutrition: prevalence, identification and impact on patients and the health care system. Int J Environ Res Public Health. 2011;8:51427.

4. Shum NC, Hui WWH, Chu FCS, Chai J, Chaw TW. Prevalence of malnutrition and risk factors in geriatric patients of a convalescent and rehabilitation hospital. Hong Kong Med J. 2005;11:234-42.

5. Kementerian Kesehatan Republik Indonesia. Pedoman penyelenggaraan tim terapi gizi di rumah sakit. Jakarta: Kemenkes RI; 2009.

6. Kementerian Kesehatan Republik Indonesia. Pedoman pelayanan gizi rumah sakit. Jakarta: Kemenkes RI; 2013.

7. Creswell JW, penyunting. Research design: qualitative, quantitaive and mixed methods approach. Edisi ke-3. California: SAGE Publications, Inc; 2009.

8. Denzin NK, Lincoln YS. Qualitative research. Yogyakarta: Pustaka Pelajar; 2009.

9. Freil M, Nielsen MA, Biltz C, Gut R, Mikkelsen BE, Almdal T. Reorganization of a hospital catering system increases food intake in patients with inadequate intake. Scandinavian J Food Nutr. 2006;50(2):83-8.

10. Grintzali GP, Babatsikou F. The significance of the application of hazard analysis critical control point system in catering hospital. Health S J. 2010;4(2):84-93.

11. Sharma RK, Sharma R. Comparative analysis of outsourced hospital dietary services vis-a vis in-house dietary services for cost containment and quality: a case study in a super spesialty tertiary hospital. J Ac Hos Adm. 2009;21(1-2):11-5.

12. Diez-Garcia RW, Japur CC, Medeiros MAT. Food and nutritional care quality indicators in hospital. J Hos Adm. 2013;2(3):132-41.

13. Diez-Garcia RW, Sousa AA, Proença RPC, Leandro-Merhi VA and Martinez EZ. Gauging food and nutritional care quality in hospitals. Nutr J. 2012;11:66.

14. Peraturan Menteri Tenaga Kerja dan Transmigrasi Republik Indonesia Nomor 19 Tahun 2012 Tentang Syarat-Syarat Penyerahan Sebagian Pelaksanaan Pekerjaan Kepada Perusahaan Lain.

15. Kondrup J. Proper hospital nutrition as a human right. Clin Nutr. 2004;23:135-7.

16. Lassen KO, Olsen J, Grinderslev E, Kruse F, Bjerrum M. Nutritional care of medical inpatients: a health technology assessment. BMC Health Services Research. 2006;6:7. 